\title{
POSZTPROCESSZOR FEJLESZTÉSE KIBER-FIZIKAI RENDSZERBEN
}

\author{
Szunyi Attila ${ }^{a}$, Andó Mátyás ${ }^{b^{*}}$, Safranyik Ferenc ${ }^{b}$ \\ a ELTE, Informatikai Kar, Savaria Müszaki Intézet, Duális gépészmérnöki BSc, 4. évf. \\ ${ }^{b}$ ELTE, Informatikai Kar, Savaria Müszaki Intézet, egyetemi docens
}

\begin{abstract}
ABSZTRAKT
CNC esztergagép posztprocesszorának létrehozása lényegesen hatékonyabb kiber-fizikai rendszerben (CPS). Egy Akira-Seiki SL25MC típusú CNC esztergagép posztprocesszorát Sinutrain szimulációs szoftver segítségével hoztuk létre Edgecam-ben. A kidolgozott eljárással csökken a szintaktikai hibák kiszúrésére fordított idő. Jelentôsen nô a CNC gép rendelkezésre állása, mert a tesztelési feladat túlnyomó része nem a valós gépen történt. Ráadásul az esetleges hibás programkódok nem okoznak ütközést a CNC gépen. Megállapítottuk, hogy a valós gépen történő tesztelés azonban nem hagyható el, itt kiemelt figyelmet kell fordítani a mozgási sebességekre és forgásirányokra.
\end{abstract}

Kulcsszavak: posztprocesszor, CAM, CNC, CPS, kiber-fizikai rendszer

\section{Bevezetés}

Az informatika fejlődésével és térnyerésével egyre jobban megváltozott a gépészet. A kézi rajzok helyét teljesen átvették a 3D-s CAD modellek és az azokból képzett rajzok. A megrajzolt alkatrészek gyártási módszereire is hatással van az informatikai fejlódés, azonban még nem ennyire látványosan. A forgácsolás terén leginkább a szerszámgépek vezérlésére volt nagy hatással. A CNC - számítógép által vezérelt - szerszámgépek már fél évszázada léteznek, szinte az összes iparágban elterjedtek. Ezek programozására számtalan módszer létezik.

A legegyszerúbb, amikor lapon írják a programkódot, majd beírják a szerszámgép vezérlőjébe. Ez az egyszerúnek tûnô, olcsó módszer azonban számos hibalehetôséget rejt magában. A korszerú szerszámgépeken, közvetlenül a vezérlőben létrehozni a programot már egy fokkal előnyösebb és gyorsabb, azonban sokszor a gyártási körülmények nem engedik meg, illetve adott esetben a programozás idejére a gép kiesik a termelésból is. Ennek kiküszöbölésére az egyik megoldás a CAM Computer Aided Manufacturing, azaz számítógéppel támogatott gyártás - szoftverek használata. A CAD rendszerek széleskörú alkalmazásának köszönhetően napjainkban minden gyártandó alkatrész 3D modellje rendelkezésre áll. Ezeket a modelleket a CAM szoftverekbe importálva létrehozhatók rá a megmunkálási programok egy átlátható, ergonomikus környezetben, akár a szerszámgéptôl távoli irodában is.

Az alkatrész összes fizikai mérete és geometriai jellemzője, amelyek a programhoz szükségesek, ilyenkor a modellból származnak, így azokat a program írásakor nem szükséges megadni. Ezáltal csökken a hibalehetôségek száma a programozás során. A CAM szoftverek használatának számos előnye van még, azonban nem szabad megfeledkezni a hátrányairól sem. Napjainkban sokféle CAM szoftver és még több fajta szerszámgép típus van. A gépgyártók pedig a termékeiket különféle

(C) ELTE, Informatikai Kar, Savaria Múszaki Intézet, 2020

*Kapcsolattartó: am@inf.elte.hu

https://doi.org/10.37775/EIS.2020.1.8 
vezérlőkkel kínálják. Ahhoz, hogy a CAM szoftverben képesek legyünk programkódot generálni, nélkülözhetetlen egy posztprocesszor. Ez tulajdonképpen egy számítógépes szoftver, ami megteremti a kapcsolatot a CAM szoftver és egy konkrét szerszámgép között.

A programkódok létrehozásánál tehát mindig figyelni kell arra, hogy milyen típusú vezérlővel rendelkezik az adott szerszámgép. A vezérlók többségéhez rendelkezésre állnak számítógépen futtatható vezérlôszimulátorok, amelyek segítségével irodai környezetben szimulálható a vezérlôk múködése.

A CNC szerszámgépek programnyelve az ún. „G-kód”. Ezeket az ISO 6983-as szabvány tartalmazza. A szerszámgépek ezen a nyelven kapnak minden lényeges utasítást: hova és hogyan mozogjanak, milyen gyorsan, milyen fordulatszámon... Emellett minden CNC gép rendelkezik valamilyen vezérlővel. A több évtizedes fejlesztés során számos vezérlő gyártó és típus alakult ki. Ezekhez kialakultak vezérlőspecifikus G-kódok is, amelyek megnehezíthetik a gépek programozását, ugyanis egyes programkódok teljesen más funkciót láthatnak el egy Siemens vezérlőn, mint például egy Fanucon [1, 2].

Egy posztprocesszor mindig egy konkrét szerszámgép és egy konkrét CAM szoftver közötti kapcsolatot teremti meg, tehát mindig egy egyedi fájl. Az általunk készített posztprocesszor az egyetem gyártástechnológia laborjában található Akira-Seiki esztergára készült, Edgecam-ben. A cikk a posztprocesszor létrehozásával, fejlesztésével és tesztelésével foglalkozik, modern informatikai környezetben. Érintjük a posztprocesszorhoz illeszkedő szerszámgép CAD modelljének szerkesztését és a megfelelő vezérlő szimulációs környezetének használatát is. A létrehozott posztprocesszor múködését teszteltük valós környezetben is. A cikkben a fejlesztési lépéseket időrendben dolgozzuk fel.

\section{Gép és módszer}

A fejlesztési folyamatot a Akira-Seiki CNC esztergagép kapcsán végeztük el. Ez az SL25MC típusú gép egy C-tengelyes eszterga, melynek vezérlésérôl egy Siemens Sinumerik 828D típusú vezérló gondoskodik. A szerszámgép a vezérlőjével az 1. ábrán látható.

A fejlesztési folyamatot a következő szoftverek támogatták:

- CAD - Autodesk Inventor Professional 2018,

- CAM - Edgecam 2018 R2,

- Szimulációs szoftver - Siemens Sinutrain 4.5.

A posztprocesszor fejlesztés leghosszabb és legdrágább folyamata a tesztelés. Ennek kiküszöbölésére a tesztelés túlnyomó részét kiber-fizikai rendszerben végeztük. Az új fejlesztési folyamat felépítését

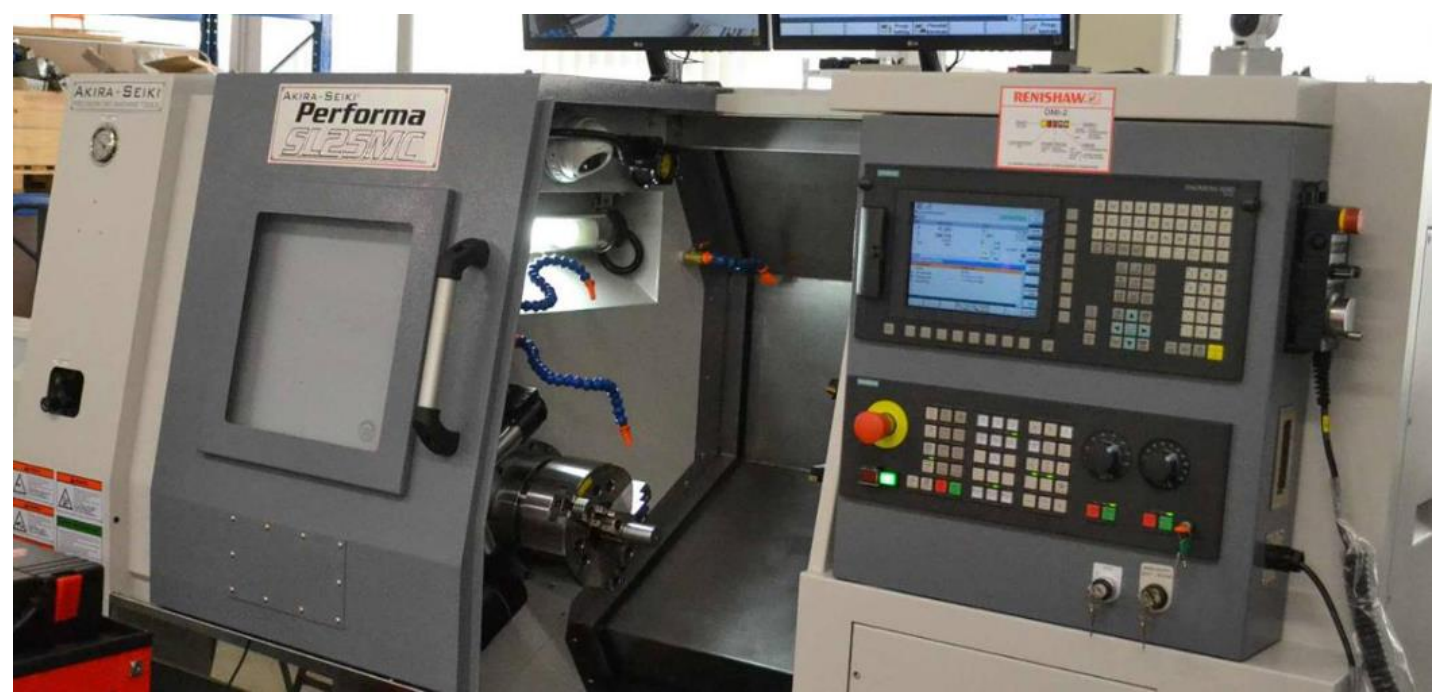

1. ábra: A szerszámgép és a vezérlője 
a 2. ábra szemlélteti. A gyakorlatban ez azt jelenti, hogy a CNC gép vezérlójéról készített biztonsági mentést importáltuk a Sinutrain vezérlőszimulátorba. Ezzel létrehoztuk a valós szerszámgép virtuális klónját, ami vezérlés szempontjából ugyanúgy viselkedik, ahogy azt a valós gép is tenné. Ebból következik, hogy minden programkód, ami a vezérlőszimulátorban helyesen futott, az a valós szerszámgépen is helyesen fut le. Azok a programkódok viszont, amelyek hibaüzenettel leálltak, a valós gépen is azonos hibaüzenettel álltak volna le.

Ez azt jelenti a gyakorlatban, hogy a posztprocesszor által generált programkódok szintaktikai helyességéról pusztán a virtuális környezetben, a számítógépem segítségével (szerszámgép nélkül) meg tudunk bizonyosodni. További előny, hogy a szerszámgépet nem veszélyeztetjük az esetleges korai és hibás programokkal.

\section{Fejlesztés fốbb lépései}

Posztprocesszor fejlesztésénél feltétlenül szükséges az adott szerszámgépról egy CAD modell. Ennek két fő kritériumnak kell megfelelnie: szimuláció biztonsága és futtathatóság. A CAM szoftverek egyik leghasznosabb funkciója a szimuláció - és annak a részeként az ütközésvizsgálat. Ennek segítségével a CAM szoftver figyelmeztetéssel megáll, ha ütközést észlel. Az ütközéseket a szerszámgép számos - elôre definiált - alkatrészén végzi a szoftver. Annak érdekében, hogy ez helyesen múködhessen, a szerszámgéprôl készült modell munkaterének teljes mértékben, minden irányban meg kell egyeznie a valós gépével. A másik fontos paraméter a modell fájlmérete, ugyanis a szimulációk és az ütközésvizsgálat nagy számításigényú folyamatok, amelyek a mai modern számítógépeket is képesek lehetnek túlterhelni, ezáltal nagymértékben lelassítani. Emiatt a fájlméretet célszerú megközelítôleg 5 megabyte környékére csökkenteni. A modell elkészítésére kétféle stratégia terjedt el. A konkrét gépről méréseket végezve felépíthetô egy komplett új modell, azonban ezt ritkábban használják. Másik amit jelen esetben alkalmaztunk, hogy a gép gyártójától kapott modellt kellő mértékben leegyszerúsítve létrehozható egy minden kritériumnak megfelelő új fájl. A 3. ábrán látható a gyártótól érkező modell. Ennek egyszerúsítése a számos bonyolult felületi elem miatt volt elkerülhetetlen. Az eredeti file 25,9 MB volt, ami jelentősen meghaladja a múködési határt. Az egyszerúsítések során egyes alkatrészeket - amelyek az ütközésszimuláció szempontjából nem relevánsak - egyszerúen kitöröltük, míg az alkatrészek többségének geometriáját egyszerúsítettük. Ennek során eltüntettük a felesleges furatokat, a csapágyakat, kötőelemeket és egyéb gépelemeket, felületeket.

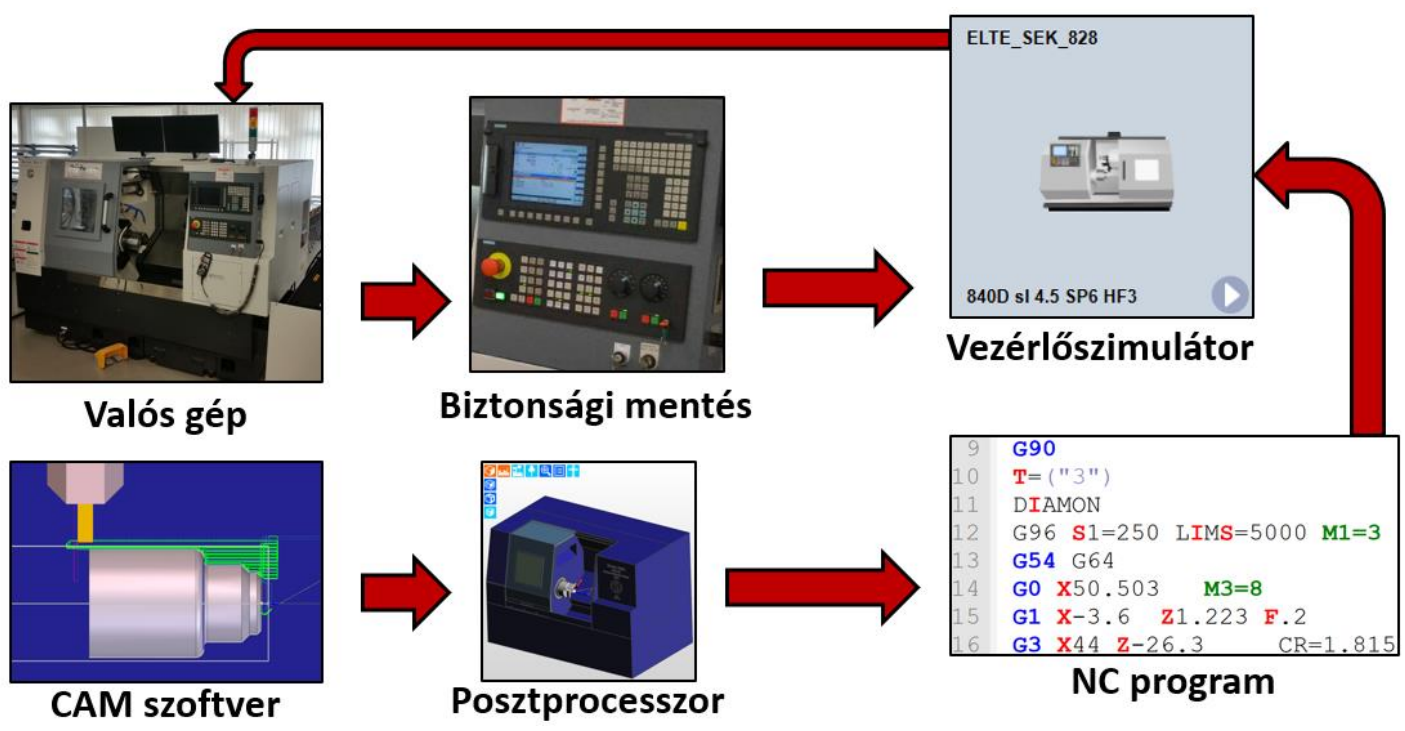

2. ábra: Kiber-fizikai fejlesztés folyamatábrája 

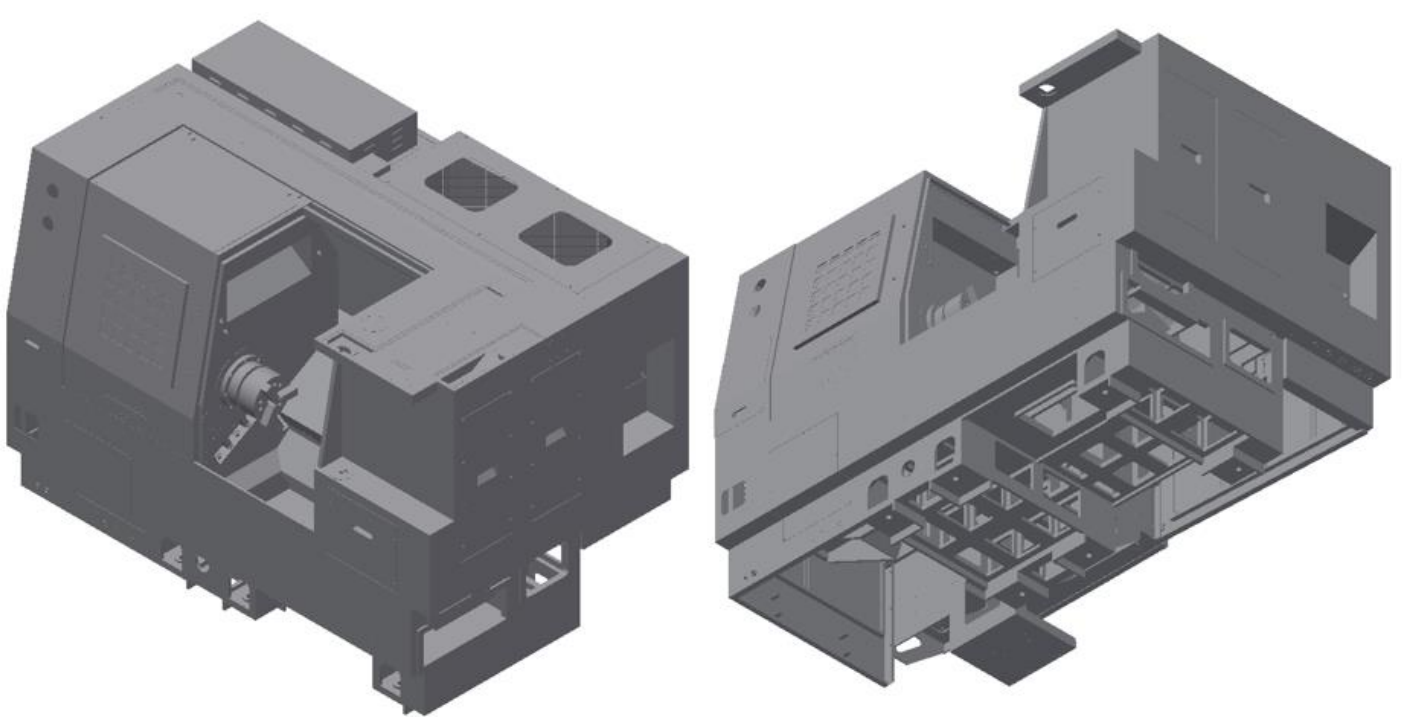

3. ábra: A gyártótól érkezô CAD modell

A posztprocesszor az Edgecam Kódvarázsló nevû menüpontjában készíthető el. A posztprocesszorok többsége sablon alapján készül. A létrehozásnál fel is kínál a szoftver számos vezérlôtípust. Ebben az esetben azonban a Sinumerik 828D nem szerepelt a listában, így a legjobban hasonlító, 840-es sablont választottuk. Ezután lehetséges az elkészített modell alapján az Edgecam-ben kinematikai szempontból is felépíteni a szerszámgépet, a 4. ábrán látható hierarchiának megfelelóen. A modell importálásával és a valós kinematikai adatok bevitelével elkészült az ütközésvizsgálat szimulációs környezete.

A posztprocesszor elkészítésének utolsó lépése, hogy az adott gépnek megfelelóen kitöltsük a paramétereket, melyek a G-kód szintaktikáját fogják meghatározni. Ez a folyamat a legidóigényesebb és ezért a legköltségesebb. További probléma, hogy hagyományos módszerrel a CNC gép ezen idő alatt nem termel - így a kiesố termelés plusz költségként jelentkezik.

\section{Tesztelés kiber-fizikai rendszerben}

A gépen futó és a sablonból válaszható két vezérlő verzió közt a gyakorlatban elenyészô különbségek vannak, azonban még helyes sablonválasztás esetén is gyakorlatilag kizárt, hogy egy posztprocesszor

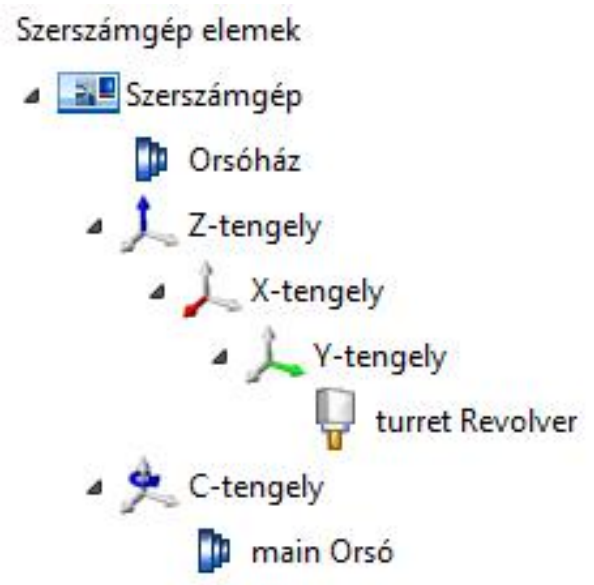

4. ábra: Posztprocesszor modellfa 
elsôre helyesen kezdjen múködni. A hibakeresésre létrehoztuk egy alkatrész 3D modelljét. Erre kezdtünk el megmunkálási programokat készíteni az Edgecam-ben, majd a megmunkálási programokat gépi programkódra fordíttattuk a posztprocesszorral. Az így generált kódot a vezérlószimulátorral teszteltük. Megszokott dolog, hogy az elsô próbálkozások rendre kudarcba fulladtak - a programok hibaüzenettel leálltak (5. ábra). Azonban ezek segítéségével lehetett következtetni a hibák forrására. Mivel a virtuális gép teljesen azonosan múködik a valós géppel, az itt kapott hibaüzenet - és hibakód - alapján a Siemens programozói kézikönyvben kikereshető, hogy mi okozta a hibás futást. A programozói kézikönyvből kikereshető, hogy mi miatt volt rossz a generált kód. Azonban az adott generált kódrészlet megváltoztatásához, az esetek többségében nem egyértelmú, hogy mit kell megváltoztatni a posztprocesszorban. A CAM rendszerek tetszólegesen bonyolult geometriákra képesek megmunkálási programokat írni, azonban az ezekból generált kódok a valóságban sokszor tagolatlanok, nehezen átláthatók és több száz sorosak lehetnek egy egyszerú alkatrész esetén is. A posztprocesszorban az egyes múveletek generálásért külön alrendszerek felelősek (pl. lineáris interpoláció, szerszámcsere vagy forgácstörôs fúróciklus kódszerkesztője). Egy egyszerű esztergálás végrehajtásánál is szükség van szerszámcserére, lineáris interpolációra - előtolással és gyorsjárattal egyaránt, hazaállásra stb. Ezáltal a generált programkódot nézve nem egyértelmú, hogy egy adott programrészlet generálásáért konkrétan melyik kódszerkesztő a felelős. Ennek felderítésére használható az Edgecam egyik diagnosztikai funkciója - a Teljes kódkészítő követés generálása. Ennek hatására a generált kódban megjelennek kiemelt sorok (6. ábra), amelyek leírják, hogy az adott kódrészlet megváltoztatására melyik kódszerkesztőt kell módosítani. Miután a posztprocesszor olyan kódokat generálti, amelyek a vezérlőszimulátorban hibátlanul futottak, következhettek a valós gépen történő tesztek.

\section{Valós tesztek és eredmények}

A valós szerszámgépen történô tesztelés rávilágított, hogy a valós tesztelést sosem szabad elhanyagolni, ugyanis a virtuális környezetben jól múködő posztprocesszor a valós gépen lezajlott első teszt során hibás munkadarabot ( 7. ábra) és törött lapkát eredményezett.Ennek oka az volt, hogy a posztprocesszorban a számos paraméter közül a főorsó forgásiránynál 3 helyett 4 volt megadva, ezáltal M3 helyett $M 4$ kóddal generálta a főorsó forgását, így az fordítva forgott. Az érték korrigálása után a program helyesen futott és a gép sikeresen megmunkálta a tervezett alkatrészt. A selejtes és a pontos munkadarab a \%. ábrán látható.

A fejlesztési módszernek köszönhetően megtakarított üzemórákat konkrétan számszerúsíteni nem könnyú feladat. Kezdetben számos hibaüzenet, sikertelen futtatás elôzte meg a múködő programokat, valamint egyes funkciók múködóképessé tétele több napot vett igénybe. A funkciók többségéhez 8-10 mintaprogram is készült, mire végül jól múködtek. A több száz tesztprogram lefuttatása, majd az ezek szerint történő korrigálás összesített munkaóráinak száma nagyságrendileg eléri a 100-at.

\section{Block 31 radius for circle programming too small}

5. ábra: Hibaüzenet és a hozzá tartozó hibakód

\begin{tabular}{|c|c|c|}
\hline 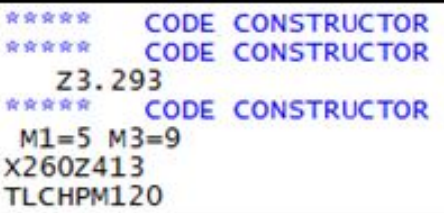 & $\begin{array}{l}{ }^{\prime} \\
\vdots\end{array}$ & 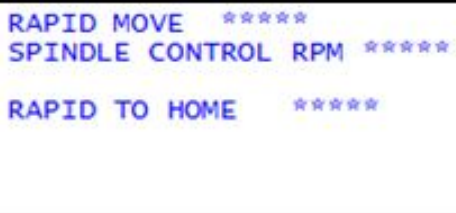 \\
\hline
\end{tabular}

6. ábra: Hibakeresés a generált programkódban 


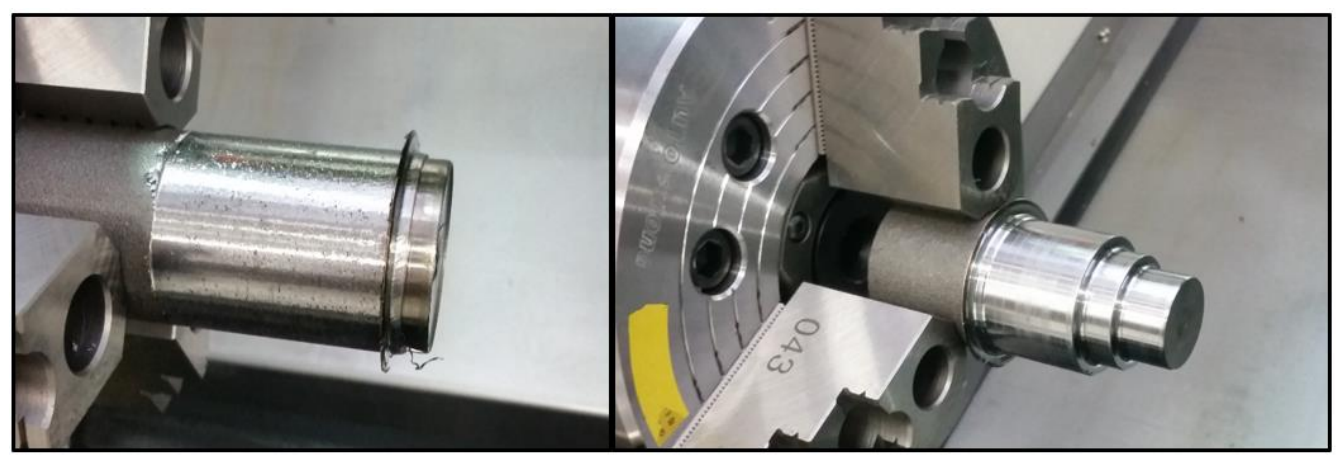

7. ábra: Elsố valós teszt eredményei

Gyakorlatilag ennyi tesztelési üzemórától biztosan mentesült a valós szerszámgép, ami jelentôs megtakarítást jelent, hiszen a CNC gép ez alatt az idő alatt is termelt. Ezen felül még fontosabb elöny, hogy a gép a tesztelés során kevésbé volt terhelve és veszélyeztetve a hibás programok miatt. Ezek a mai, egyre jobban kiélezett gyártói versenyben egy termelő vállalat számára nem elhanyagolható szempontok.

\section{6. Összefoglalás}

A munkánk során elkészítettük az esztergagép leegyszerúsített modelljét és létrehoztunk egy 2tengelyes esztergálási funkciókkal múködő Edgecam-es posztprocesszort, amelynek funkcionalitását teszt munkadarabok elkészítésével is igazoltuk. A tesztelési módszernek köszönhetôen számos gépi üzemórát tudtunk megtakarítani, valamint megkíméltük a szerszámgépet az ütközések esélyétól is. A CPS rendszerben történő fejlesztés tapasztalatai, hogy a vezérlőszimulátorban történő tesztelés kiválóan alkalmas a programozási szintaktikai hibák korai stádiumú kiszúrésére, azonban egyes jelenségek a szimulátorban nehezen - vagy akár egyáltalán nem - érzékelhetook helyesen. Ezek fóként a valós mozgásokhoz kapcsolódnak, például a forgási irányok és a mozgási sebességek. Az elért eredményt a 8. ábra mutatja be.

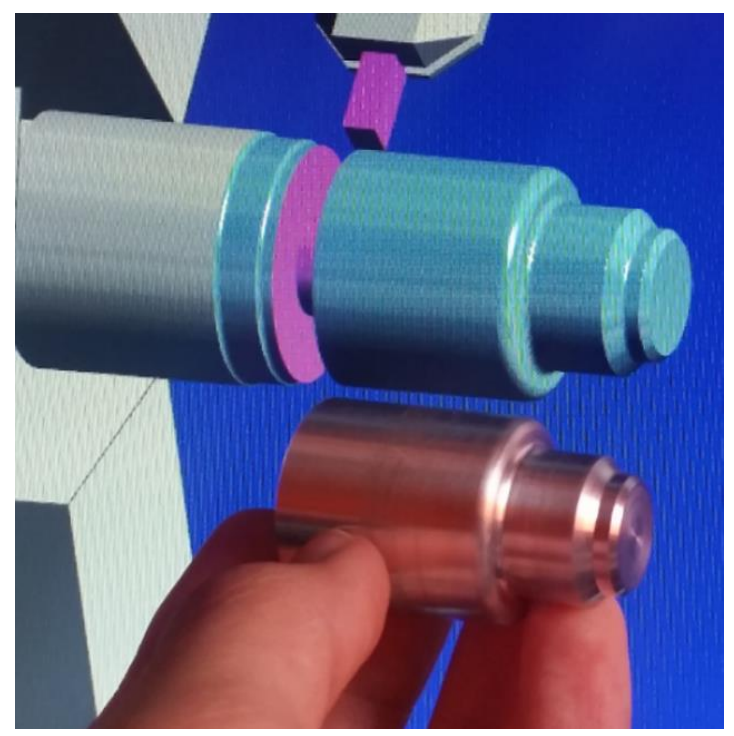

8. ábra: Teszt alkatrész az Edgecam-ben és a valóságban 


\section{Köszönetnyilvánítás}

Az ED_18-1-2019-0030 szerződésszámú projekt (Alkalmazásiterület-specifikus nagy megbízhatóságú informatikai megoldások tématerület) a Nemzeti Kutatási Fejlesztési és Innovációs Alapból biztosított támogatással, a Tématerületi kiválósági program támogatásával valósult meg.

\section{Irodalomjegyzék}

[1] Mátyási G. és Sági G., Számítógéppel támogatott technológiák, Múszaki Könyvkiadó Kft., Budapest, 2009.

[2] Boór F., Hervay P., Kakuk Gy., Markos S., Mátyási G. és Mikó B., CAM Tankönyv, Typotex Kiadó, Budapest, 2012. 